Article

\title{
Impact of Ethanol Plant Location on Corn Revenues for U.S. Farmers
}

\author{
Ani L. Katchova ${ }^{1, *(1)}$ and Ana Claudia Sant'Anna ${ }^{2}$ (D) \\ 1 Department of Agricultural, Environmental, and Development Economics, The Ohio State University, \\ Columbus, $\mathrm{OH} 43210$, USA \\ 2 Division of Resource Economics and Management, West Virginia University, Morgantown, \\ WV 26506, USA; ana.santanna@mail.wvu.edu \\ * Correspondence: katchova.1@osu.edu
}

Received: 22 October 2019; Accepted: 15 November 2019; Published: 19 November 2019

check for updates

\begin{abstract}
Ethanol production has rapidly expanded over the past few years. The opening of an ethanol plant can increase local demand for corn, pressuring increases in local corn basis. But how does this affect corn contract prices and revenues? At the farm level, the impact of an ethanol plant on local corn contract revenues is still unknown. Data from the USDA Agricultural Resource Management Survey suggests that corn contract revenues in counties with ethanol plants are higher than corn contract revenues in counties without ethanol plants at similar prices. We estimate the impact of ethanol plants on local corn contract revenues by running non-spatial and spatial difference-in-difference models. A statistically significant effect of ethanol plant location on corn contract revenues within the same county was not found, but rather a statistically significant effect of ethanol plants on corn contract revenues for farmers located in adjacent counties. Local competitive advantage, not the presence of an ethanol plant, may be the reason for observed higher revenues in counties with an ethanol plant. Therefore, policymakers should focus their resources in promoting greater efficiency in corn production to boost farmers' revenues.
\end{abstract}

Keywords: biofuels; spatial difference-in-difference; corn markets

\section{Introduction}

Biofuel markets and policies are often related to matters of national security, the environment, and food security. In the U.S., ethanol production has rapidly expanded over the last few years. From 1999 to 2017, the number of biofuel refineries increased from 50 to 213 [1,2]. Along with the increase in the number of biorefineries came an increase in the share of corn supplied to ethanol production and of corn prices (Figure 1).

Increases in ethanol production may benefit local corn producers. The opening of an ethanol plant, for instance, can increase local demand for corn, pressuring increases in local corn basis [3]. This impact, though, may not be lasting [4,5]. In fact, in some areas, the presence of an ethanol plant has been linked to lower corn prices [6,7], providing mixed evidence for the effect of ethanol plants on corn prices in previous studies. Furthermore, analysis of the data from the USDA Agricultural Resource Management Survey (ARMS), shows that, on average, farmers in counties with ethanol plants receive the same prices for corn as those located in counties without plants (Figure 2a). Therefore, can the opening of an ethanol plant really benefit the local farmer? The same data from the USDA show that farmers in counties with ethanol plants do, however, receive higher corn revenues (Figure 2b), a phenomenon that is not considered in previous studies. Our study fills this gap in the literature by estimating the impact on farmers' corn revenues from having an ethanol plant in their county. 


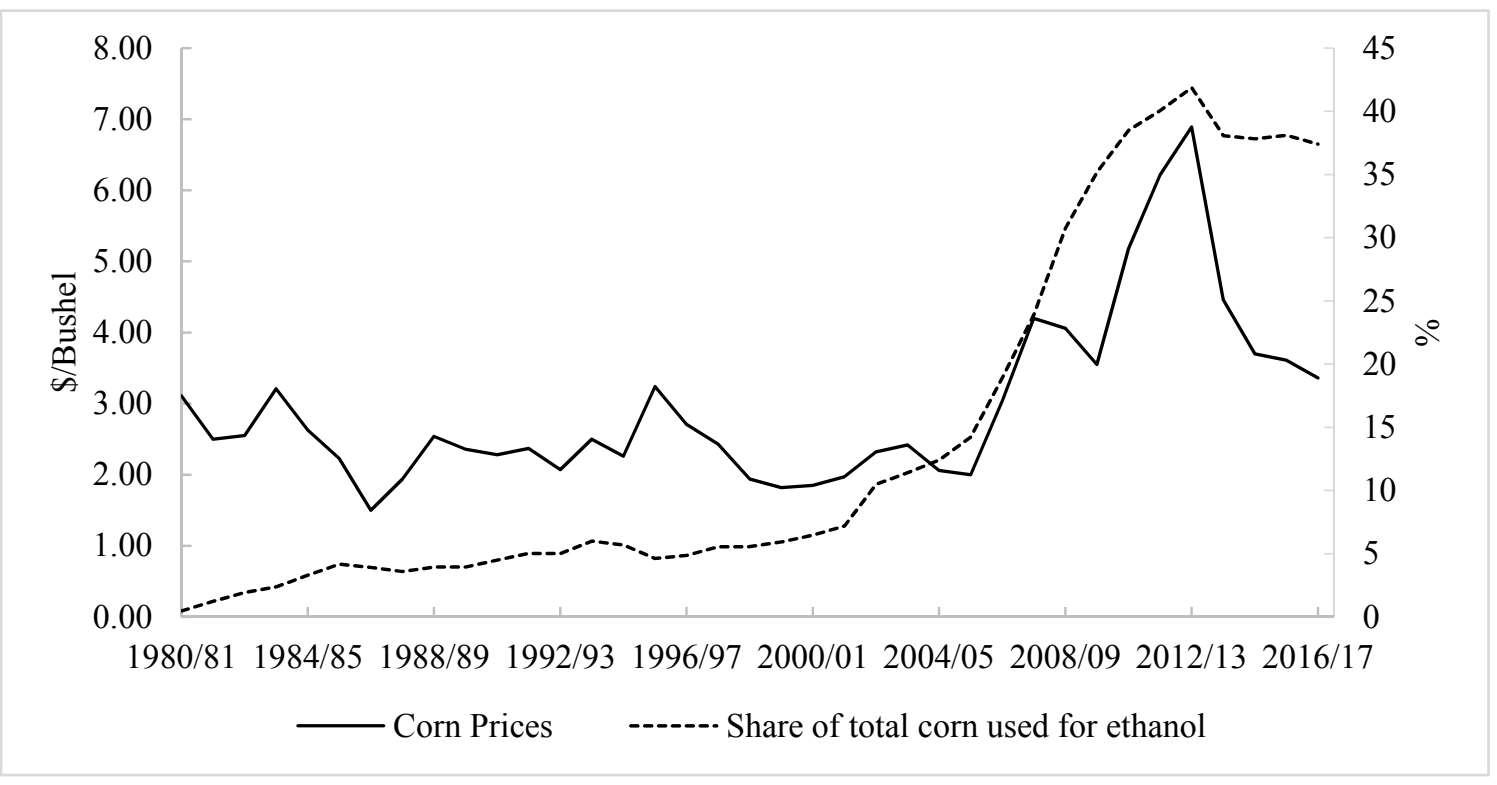

Figure 1. Corn prices against the share of total corn used for ethanol, from 1980 to 2017. Source: USDA 2017.

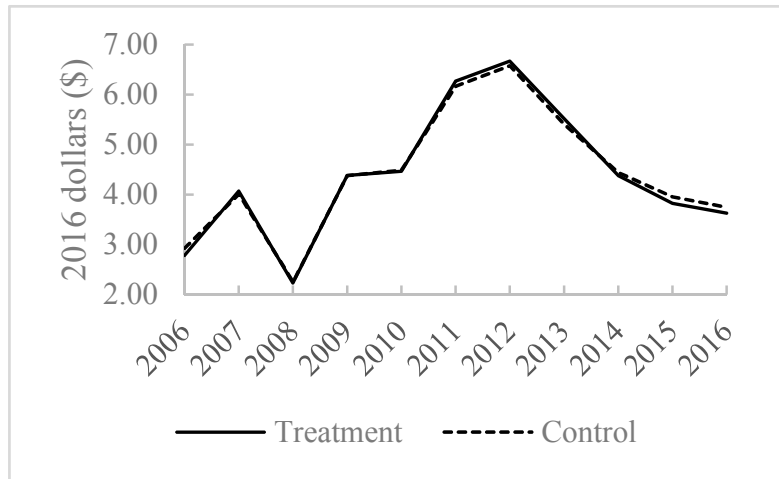

(a)

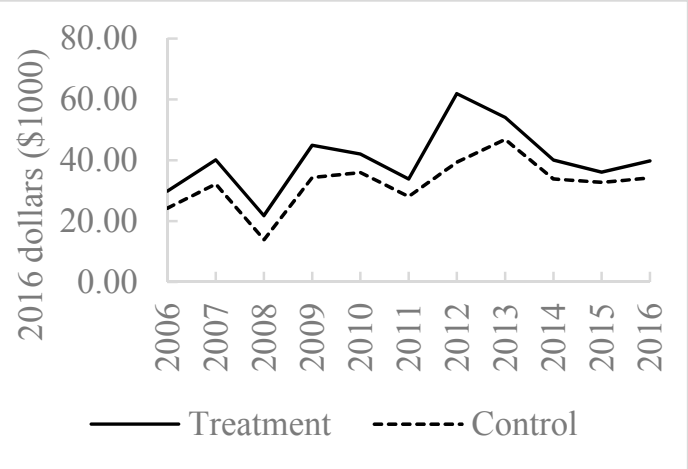

(b)

Figure 2. (a) Median contract corn prices for farmers located in counties with (treated group) and without (control group) an ethanol plant from 2006 to 2016. Source: ARMS, USDA; (b) Median contract corn revenues for farmers located in counties with (treated group) and without (control group) an ethanol plant from 2006 to 2016. Source: ARMS, USDA.

The location of an ethanol plant is determined by factors such as access to feedstock, trends in corn production, government incentives, local amenities, and infrastructure [8-10]. Lambert et al. [9] find that infrastructure, markets, and subsidies can provide counties with a comparative advantage in charming ethanol plants to the county. The impact and duration of an ethanol plant location or ethanol production capacity on local corn markets can be diverse. Previous studies provide varying results on how ethanol plant location impact local corn supply [11-13], farmers' cropping decisions [14], and local corn market prices $[4,5,15,16]$. Upon closer examination of data from the Agricultural Resource Management Survey (ARMS) counties with an ethanol plant generally receive higher revenues than counties without, at the same corn prices (Figure 2a,b).

There is lack of consensus on how ethanol plant location and production capacity affect corn production. Using an acreage response model, Fatal and Thurman [11] find that an increase of 1 million gallons in ethanol production capacity increases planted corn acreage by 5.21 acres. Similarly, Motamed, McPhail, and Williams [12] find, in locations with previously low corn acreage, significant acreage response due to changes in the ethanol market. Du, Hennessy, and Edwards [14] show that increases 
in corn prices causes farmers to switch from non-cropped land to row crops (e.g., from forage crops to row crops). Distance to an ethanol plant also affects crop rotation decisions (e.g., from corn-soybean to corn-corn), allowing more corn to be produced [13]. The distance to the ethanol plant, though, may not always be the cause for changes in corn acreage. Ifft et al. [10] argue that land use change maybe mostly driven by general price changes rather than by the location of an ethanol plant.

Lack of consensus is also present with regard to the impact of ethanol plants on local corn basis. McNew and Griffith [5] find an inverse relationship between the distance of an ethanol plant to markets and corn prices: Facilities near terminal markets have a smaller impact on corn basis prices than those further away. Expanding on McNew and Griffith's [5] model, Fatal [17] finds a premium of $\$ 0.04 /$ bushel on local corn, depending on the market, the number of ethanol plants, the total production capacity, and the distance from ethanol plants to corn suppliers. However, being in the vicinity of an ethanol plant is no guarantee of higher local corn prices [7]. Katchova [2] finds no effect from the ethanol plant location on local corn prices. O'Brien [6] finds a negative impact from ethanol plant proximity on corn prices using 2008 corn prices in Kansas. Furthermore, considering four ethanol producing states, Lewis [4] finds increases in corn basis in Michigan, Kansas, and Iowa, but decreases in corn basis in Indiana, following the opening of a new plant. In fact, Lewis [4] finds that the local corn basis decreases as the number of months the ethanol plant is in operation increases. In the case of this study, the data support the theory that the ethanol plant location does not impact corn contract prices but rather corn contract revenues.

Pre-existing market conditions and geographical location play an important role in determining changes in corn prices [16]. Corn is an important raw input in ethanol production. Haddad, Tayler, and Owusu [18] identify ethanol plants as a supply-oriented firm, given the high share that corn occupies in the production costs. Rask [19] finds a corn input price elasticity of (-3.03), meaning that small changes to corn prices provoke larger changes to the amount of ethanol produced. Hence, the demand for corn as an input is likely to be elastic. Furthermore, there is evidence that ethanol plants will halt production when corn prices go over a certain level and that corn farmers are price takers $[20,21]$. As such, the location of ethanol plants may occur in counties where there is excess corn supply such that an increased demand for corn has a limited effect on local corn prices. Ethanol plants may also be located in areas where farmers have limited bargaining power and are price takers. Katchova [22] finds that corn contracts in regions with larger spot markets have higher prices than in those with limited or no access to spot markets. When farmers have no influence on the corn contract price, they can increase their revenue by increasing the quantity supplied. This could explain why corn contract prices do not differ between counties with and without ethanol plants, but revenues do. Counties with ethanol plants may have a competitive advantage on corn production over those without one. This allows farmers in counties with a competitive advantage to have higher corn productivity at lower costs, thus receiving higher revenues at similar corn prices. As Porter [23] describes, cost leadership is a form of competitive advantage, which occurs when you can produce the same product at the lower cost than your competition [23].

The main objective of this study is to investigate the impact of ethanol plants on local corn contract revenues in more recent years. Understanding how ethanol plants may impact corn producers' welfare may provide guidance on possible impacts from the opening of other ethanol plants (e.g., ethanol plants that produce ethanol from sorghum) or agribusiness industries (e.g., the installation of dairy processing facilities) on the local county. For example, if the location of a plant is associated with surrounding corn producers receiving higher corn revenues, policy makers may decide to motivate the siting of ethanol plants in certain regions aiming to increase farmer's corn revenues. For instance, in Brazil, states in the Cerrado region attracted private ethanol facilities to their counties by investing in infrastructure and providing fiscal incentives [24]. For the farmer, the news of a new ethanol plant may help with their cropping decisions as they seek to maximize profits [15]. The ethanol industry may use the advantages from an ethanol plant siting to negotiate financial benefits from counties or states where they are deciding to build plants. 


\section{Materials and Methods}

We assume farmers are price takers in this market (i.e., they cannot influence corn prices). In this study, since we observe marketing corn contracts, we assume that the farmer goes through a revenue maximization process to decide the quantity of corn to offer given the corn contract price they face. In order to check whether the higher revenues are due to competitive advantage or due to the proximity to the ethanol plant, total revenue is modelled as a function of farm business related factors (e.g., farm assets and operator characteristics), a dummy for whether there is an ethanol plant in the county and economic factors. The objective is to identify whether the higher revenues are due to economic growth, farm business-related factors, or the presence of an ethanol plant in the county.

We test this hypothesis by using difference-in-difference models where we can compare the outcome measures (i.e., corn revenues) of corn producers in counties with and without an ethanol plant. The farmer chooses the optimal quantity to offer in the contract taking into consideration the capital and labor available. We model corn contract revenues as a function of the capital available in the farm, an index of labor available in the county, characteristics of the farm operation (i.e., farm size and level of specialization), farm operator characteristics (i.e., age and education), as well as county economic characteristics.

The difference-in-differences (DID) estimation compares the difference in outcomes (e.g., revenues) between the treated observations (corn contracts located in counties with an ethanol plant) and control observations (corn contracts located in counties without an ethanol plant). Two differences are taken into account: 1) Differences in outcomes from time one to time two; 2) the difference between observations that received the treatment and those that did not. The difference-in-differences model is:

$$
y_{i t}=\alpha+\beta t_{i t}+\gamma d_{i t}+\delta t_{i t} d_{i t}+\phi x_{i t}+e_{i t}
$$

where $y_{i t}$ is the log of corn revenues for each contract $i$ for the initial or second period, $t_{i t}$ is a dichotomous variable, which takes on the value of 1 if the observation is in the second period (i.e., 2016) and 0 otherwise (i.e., 2015), $d_{i t}$ is a dichotomous variable equal to 1 if the contract belongs to a county with an ethanol plant or more and 0 if it does not, $t_{i t} d_{i t}$ is the interaction term between the time and treatment dichotomous variables, $x_{i t}$ are characteristics that influence revenue (i.e., producer, county, and operation characteristics), and $e_{i t}$ is the error term. $t_{i t} d_{i t}$ is the difference-in-differences measure. It measures the effect of the treatment on the treated group. It controls for similar time differences between the treatment and control groups. It represents the percentage increase in corn revenues due to spatial closeness to an ethanol plant after general spatial (e.g., location in more rural areas) and time effects (e.g., changes in commodity prices) are accounted for.

By estimating the difference-in-differences model using the ordinary least squares estimator, we assume each observation to be independent of all other observations in the data. If observations are correlated inside of a cluster, then each observation will contain less exclusive information. In this study, data from farmers within the same county may be correlated. Therefore, the standard errors are corrected for the intraclass correlation within clusters using the robust cluster variance estimator:

$$
V_{\text {cluster }}=\left(X^{\prime} X\right)^{-1} \sum_{j=1}^{n_{c}} u_{j}^{\prime} u_{j}\left(X^{\prime} X\right)^{-1},
$$

where $X$ consists of all variables and the constant, $u_{j}=\sum_{j \text { cluster }} e_{i} X_{i}$, and $n_{c}$ contains all the clusters. In this study, the observations represent the farmers while the clusters the counties where their farm operations are located.

As an extra step, we apply difference-in-differences techniques for spatial data, which allow for spatially correlated treatments. The spatial DID model offers an advantage over the non-spatial DID model for it accounts for spatially correlated treatments and spatial interaction in treatment responses [25]. The method allows for the estimation of spillover effects (i.e., indirect treatment effects). The interaction term $\left(t_{i t} d_{i t}\right)$ is re-written to incorporate a spatially weighted contiguity matrix $\left(W_{i i}\right)$ : 


$$
y_{i t}=\alpha+\beta t_{i t}+\gamma d_{i t}+\delta t_{i t} d_{i t}+\tau W_{i i} d_{i t} \cdot t_{i t}+\phi x_{i t}+e_{i t}
$$

where $\tau=\rho \delta$ and · indicates element by element multiplication (Delgado and Florax 2015). In the absence of spatially correlated treatments, $\rho=0$, and the model reverts to the non-spatial DID Equation (1) [25]. The average treatment effect (ATE), average direct treatment effect (ADTE), and average indirect treatment effect (AITE) can be estimated from the parameters obtained in (3) [25]:

$$
\begin{gathered}
A T E=\delta(1+\rho \overline{W D}), \\
A D T E=\delta, \\
A I T E=\tau \overline{W D},
\end{gathered}
$$

where $\overline{W D}$ is the average proportion of counties that border counties with ethanol plant. Spillover effects from the ethanol plant are given by AITE. The AITE coefficient measures the effect on local corn contract revenues in counties bordering those with an ethanol plant. The effect is on corn contract revenues in counties without an ethanol plant. ADTE captures the direct effect on corn contract revenues in a county with at least one ethanol plant.

Models are tested for misspecification and omitted variable bias. The omitted variable bias was tested using the Ramsey regression equation specification-error test [26]. The null hypothesis of the Ramsey RESET test is that there are no omitted variables. A rejection of the null hypothesis may point to possible endogeneity issues in the model. To check for misspecification, the link test was run. This test verifies whether the coefficient of the transformation of the dependent variable is statistically significant. As such, the null hypothesis is that the coefficient of the dependent variable squared is equal to zero $[27,28]$. The non-spatial difference in difference estimations and the statistical tests were conducted in Stata 14 through the NORC platform. The spatial estimations were conducted in $\mathrm{R}$ following the study and codes by Delgado and Florax [25].

\section{Data and Descriptive Statistics}

This study uses data from various sources. Information on the ethanol biorefineries was obtained from the Renewable Fuels Association, as well as the Nebraska Energy Office. We focus on ethanol plants that use corn as their primary input. The latitude and longitude of each county is obtained from the Census U.S. Gazetteer files. For county level weight matrix, an adaptation of the contiguity matrices for county levels from Merryman [29] was made. The choice of counties with ethanol plants is limited to the ones present in the ARMS data. ARMS are secondary data collected by the USDA's National Agricultural Statistics Service (NASS). In order to gain access to farmer level information, considered confidential information, the reader needs to contact NASS and fill out the appropriate forms. It surveys farmers and ranchers on various aspects of their farming practices at various stages of the year during different phases [30]. NASS samples farmers from two main sampling frames: List and area frames. ARMS is also stratified and probability weighted. Weights are assigned to each observation in order to account for the probability of the observation being selected. NASS uses a jackknife re-sampling process, consisting of 30 extra weights obtained from NASS to predict the variations for every data item [30]. As such, estimations conducted in this study use the probability weights provided by the ARMS dataset. All monetary values are indexed in 2016 dollars using the consumer price index.

The matching criteria used to join the two datasets were county for the location of the ethanol plants and farms. The analysis is conducted with data for the top ethanol producing states: Illinois, Indiana, Iowa, Kansas, Michigan, Minnesota, Missouri, Nebraska, North Dakota, Ohio, South Dakota, and Wisconsin. Together, these states produce close to $90 \%$ of the total U.S. corn production [31]. The DID model requires two periods to isolate general corn revenues changes over time. The initial period was 2015 and the ending period 2016, namely the most current data available. The DID model 
requires control and treatment to have constant trends over time. We believe that in one year, there will be less variation in the county and thus we can isolate the effect by the ethanol plant in comparison to when we use a longer timeframe. We believe that one year is enough to measure the impact of an ethanol plant on farmer's revenues for two reasons: (1) The decision on the amount of corn to plant is annual; (2) the impact of ethanol plant on corn contract prices has been found to change monthly [4].

The spatial weights matrix of $\mathrm{N} \times \mathrm{N}$ dimensions was constructed by adapting the contiguity matrices for county levels from Merryman [29]. The spatial weights matrix by Merryman [29] identifies all neighboring counties in the U.S. using contiguity matrices. As such, if county $i$ and county $j$ are neighbors, then the element $\mathrm{w}_{\mathrm{ij}}$ of the matrix $\mathrm{W}$ has a value of 1 and a zero otherwise. In addition, a county is not considered to be its own neighbor (i.e., $\mathrm{w}_{\mathrm{ii}}=0$ ). Given that not all counties are represented in ARMS and in our study area, we adapt the spatial weight matrix by eliminating the rows and columns identifying counties outside of our study area. By eliminating the rows and columns of counties outside of the sample, we avoid forcing non-neighbor counties to become neighboring counties. For example, if we start with the following matrix with counties A, B, C, D, and neighbors $(\mathrm{A}, \mathrm{B}),(\mathrm{B}, \mathrm{C}),(\mathrm{C}, \mathrm{D})$ :

$$
W_{i j}=\left[\begin{array}{cccc}
0 & 1 & 0 & 0 \\
1 & 0 & 1 & 0 \\
0 & 1 & 0 & 1 \\
0 & 0 & 1 & 0
\end{array}\right],
$$

and wish to transform the matrix to reflect the counties in our sample, say $A$ and $D$, we would eliminate rows 2 and 3 , as well as columns 2 and 3 from $W_{i j}$, ending up with the matrix $\left(N_{i j}\right)$ where there are no neighbors:

$$
N_{i j}=\left[\begin{array}{ll}
0 & 0 \\
0 & 0
\end{array}\right]
$$

ARMS is not a panel data survey; as such, not all data on contracts are available in both years for all counties. We control for the unbalanced nature of the dataset by clustering standard errors at the contract level in a county. Information on the dependent variable, corn contract revenues, came from the ARMS. We consider as corn contract revenues the total dollar amount received from corn marketing contracts. Marketing contracts are agreements that determine price and quantities of a product to be delivered. Agricultural contracts make up a significant portion of U.S. agricultural production [32]. Corn costs represent $50 \%-70 \%$ of operational costs [33]; as such, ethanol plants may prefer to sign contracts with nearby corn producers as a protection against volatile corn markets and to ensure a steady processing flow [34]. Hence, we focus on corn contracts. In addition, farm characteristics such as a diversification entropy index, land tenure, farm size in terms of total assets, farm typology, operator age, and education also came from ARMS and were hypothesized to affect corn revenues [35]. The diversification entropy index ranges from 0 to 1 and provides a measure of farm diversification [36]. For example, a farm producing only corn would have a diversification entropy index of 0 and a fully diversified farm would have a diversification entropy index of 1 . Specialization in corn production may lead to gains in economies of scale leading to higher revenues. County level characteristics included indicators for a farming dependent county, and a rural county index from the U.S. Census. These are included to control for economic factors affecting corn contract revenues (e.g., more rural counties may have lower corn contract revenues due to lower wages or lower corn production costs).

Table 1 displays information on the summary statistics of the data used in the model. The average corn contract revenues in $2015 / 2016$ were $\$ 77,851$. Among the counties in the sample, $28 \%$ have an ethanol plant and $18 \%$ are dependent on farming. Over half of the data (i.e., $56 \%$ ) is from 2016, the rest of the observations are from 2015. The interaction term between the time and treatment dummy variables shows that $15 \%$ of the corn contracts in 2016 were in counties with an ethanol plant. The average farm size, measured as total assets, was about $\$ 3.5$ million, with $37 \%$ of farms having assets over $\$ 3$ million. The principal operator was, on average, 54 years old, operated on average a farm size between an intermediate and commercial farm (i.e., with a farm typology of 2.5), and had, on average, 
some college level education. Farm Typology is split into 1-Family farms, 2-Intermediate Farms, and 3-Commercial Farms, see Hoppe and MacDonald [37]. There were 629 counties included in the analysis.

Close to one-third of the observations are in the treated group (i.e., farmers with corn contracts located in counties with ethanol plants) and two-thirds are in the control group (i.e., farmers with corn contract revenues in counties without ethanol plants). In order to check for similarities between the treated and control groups, balancing tests are conducted (see Table 2). Results from the t-tests show that treatment and control groups had similar characteristics and that the control group was a valid counterfactual group. Except for operator education in 2015, for all variables, the hypothesis that the mean of the treatment group is different than that of the control group is rejected at a $5 \%$ statistical significance level. The statistically significant difference in education averages is not an issue since the averages, when rounded off belong to the same categorical level (i.e., 3).

Table 1. Descriptive statistics.

\begin{tabular}{|c|c|c|c|}
\hline Variable & Definition & Mean & $\begin{array}{l}\text { Standard } \\
\text { Deviation }\end{array}$ \\
\hline Ethanol plant Dummy & 1 if the county of farmer has an ethanol plant & 0.28 & 0.45 \\
\hline Time Dummy & 1 if observation is in the second year & 0.56 & 0.50 \\
\hline $\begin{array}{l}\text { Ethanol plant dummy* } \\
\text { time dummy }\end{array}$ & $\begin{array}{l}\text { Interaction term measuring the } \\
\text { difference-in-differences effect }\end{array}$ & 0.15 & 0.35 \\
\hline Corn contract revenue & Total amount in received in dollars of 2016 & $\$ 77,851$ & $\$ 126,626$ \\
\hline $\begin{array}{l}\text { Log corn contract } \\
\text { revenue }\end{array}$ & Natural logarithm of the corn contract revenue & 10.41 & 1.36 \\
\hline $\begin{array}{l}\text { Entropy diversification } \\
\text { index }\end{array}$ & $\begin{array}{l}\text { Diversification index defined by ERS-USDA that } \\
\text { ranges between } 0 \text { and } 1 \text {. Higher values } \\
\text { represents higher levels of diversification }\end{array}$ & 0.24 & 0.11 \\
\hline Land tenure & Proportion of owned to total land & 0.52 & 0.56 \\
\hline Land tenure (dummy) & $\begin{array}{c}1 \text { if the ratio of the area owned to operated is } 0.50 \\
\text { or more }\end{array}$ & 0.45 & 0.50 \\
\hline Farm size & Total assets in 2016 dollars & $\$ 3,475,695$ & $\$ 5,455,123$ \\
\hline Farm Size (dummy) & 1 if the total assets are greater than 3 million & 0.37 & 0.48 \\
\hline Operator age & Age of the operator in years & 54.08 & 13.26 \\
\hline Operator education & Operator education in categories from 1 to 4 & 2.96 & 0.86 \\
\hline Farm Typology & $\begin{array}{l}\text { Farm classification developed by the USDA } \\
\text { ranging from } 1-3\end{array}$ & 2.48 & 0.78 \\
\hline $\begin{array}{l}\text { Farming dependent } \\
\text { county }\end{array}$ & $\begin{array}{l}\text { Based on U.S. Census Economic dependency } \\
\text { index, where } 1 \text { if county is farming dependent }\end{array}$ & 0.18 & 0.38 \\
\hline Low employment county & $\begin{array}{c}\text { Index defined by the U.S. Census. It equals } 1 \\
\text { when it is a low employment county }\end{array}$ & 0.00 & 0.03 \\
\hline $\begin{array}{l}\text { Urban-rural } \\
\text { county index }\end{array}$ & $\begin{array}{c}\text { Index defined by the U.S. Census ranging from } \\
1-9 . \text { Higher numbers represent more } \\
\text { rural locations }\end{array}$ & 5.28 & 2.36 \\
\hline Number of observations & Number of corn contracts & 3003 & \\
\hline Number of clusters & Number of distinct counties & 629 & \\
\hline
\end{tabular}

Notes: DID: Difference-in-difference. Farm size and tenure dummies were used in the estimation instead of the continuous variables because it produced a more robust model. Farm Typology is split into 1-Family farms, 2-Intermediate Farms, and 3-Commercial Farms. Operator education is split into 1-less than high school diploma, 2-High School, 3-Some college (includes associates degree) and, 4-4-year college graduate and beyond. The average corn contract price was $\$ 3.81$. 
Table 2. Balancing tests: $p$-values and averages.

\begin{tabular}{|c|c|c|c|c|c|c|}
\hline \multirow{2}{*}{ Variable } & \multicolumn{2}{|c|}{2016 (Average) } & \multirow{2}{*}{$P$-Value } & \multicolumn{2}{|c|}{2015 (Average) } & \multirow{2}{*}{$P$-Value } \\
\hline & Control & Treatment & & Control & Treatment & \\
\hline Entropy & 0.23 & 0.25 & 0.15 & 0.23 & 0.24 & 0.32 \\
\hline Land tenure & 0.51 & 0.45 & 0.20 & 0.53 & 0.57 & 0.47 \\
\hline Farm size & $\$ 3356$ & $\$ 3714$ & 0.27 & $\$ 3277$ & $\$ 3768$ & 0.14 \\
\hline Operator age & 52 & 54 & 0.40 & 54 & 56 & 0.13 \\
\hline Operator education & 2.93 & 2.96 & 0.73 & 3.06 & 2.88 & 0.03 \\
\hline Farm Typology & 2.53 & 2.66 & 0.14 & 2.41 & 2.49 & 0.38 \\
\hline Farming dependent county & 0.20 & 0.17 & 0.34 & 0.20 & 0.13 & 0.08 \\
\hline Urban-rural county index & 5.28 & 5.25 & 0.88 & 5.27 & 5.54 & 0.21 \\
\hline Observations & & & & & Control & Treatment \\
\hline \multicolumn{3}{|c|}{ Number of corn contracts } & & & 2118 & 885 \\
\hline \multicolumn{3}{|c|}{ Percentage of contracts in each group (\%) } & & & 71 & 29 \\
\hline
\end{tabular}

Note: Control group are counties without an ethanol plant while treated group are counties with an ethanol plant.

\section{Results and Discussion}

Non-spatial and spatial difference-in-differences models are estimated to analyze whether farmers located in the same county or adjacent to counties with ethanol plants incur additional corn revenues than those located in counties without an ethanol plant. Estimation results of the non-spatial and a spatial difference-in-differences (DID) models are presented in Table 3. Both models have an $\mathrm{R}^{2}$ of 0.35 , meaning that they explain $35 \%$ of the variation (i.e., the distance between the actual value and the mean). The presence of misspecification and omitted variable bias were tested for and rejected at a 5\% statistical significance level. The standard errors are larger than standard errors produced by an ordinary least squares regression due to the clustering of the standard errors. The non-spatial and a spatial difference-in-differences (DID) models provided coefficients of similar magnitudes and of the same sign. In the spatial DID model, the coefficient associated with the spatial weight matrix and treatment dummy and the time dummy (Wdt) was statistically significant, meaning that the model did not revert to the non-spatial DID model [25]. Additionally, not controlling for the spatial treatment correlation would have rendered the treatment estimate of the non-spatial difference-in-difference model biased and inconsistent [25]. Since the dependent variable, corn revenue, was logged, the coefficients displayed in Table 3 are interpreted as the percentage change in corn revenue (e.g., if the farm is intermediate its corn revenue would be $33 \%$ higher than that of a small farm).

The difference-in-differences (DID) effect in both the non-spatial and spatial model were not statistically significant, indicating that we were unable to find a statistically significant impact from ethanol plants on corn contract revenues in their host counties (Table 3). The DID effect of the non-spatial difference-in-differences model is equivalent to the average treatment effect of the spatial difference-in-differences model. The average direct (ADTE) and average indirect (AITE) treatment effects of the spatial difference in differences model are displayed in the bottom section of Table 3 . In the spatial model, ADTE was not statistically significant, but AITE was, meaning that ethanol plant siting has positive spillover effects onto adjacent counties (Table 3).

The results show that the higher revenues observed in counties with an ethanol plant are due to factors other than the presence of an ethanol plant. These may be counties with an excess supply of corn and hold a competitive advantage over corn production. These results eco the findings of Sarmiento et al. [8] and Lambert et al. [9] that find that the site selection of an ethanol plant is predominantly based on feedstock availability. Another possible explanation for our results is that farmers in these counties may also have lower bargaining power and be willing to accept a lower corn contract price, making up for their losses by increasing the quantity of corn supplied. Factors related to the farm business and the county have a statistically significant impact on local corn contract 
revenues. Farms with over three million dollars in assets received $65 \%$ more in corn revenues than those with smaller assets. Intermediate farms (those with sales up to $\$ 249,999$ ) had 33\% higher corn revenues than small family farms, while commercial farms (those with sales of $\$ 250,000$ or more) earned $123 \%$ more in corn revenues than small family farms (for information on the farm typology, see Hoppe and MacDonald [37]). This difference in revenues may be a result of economies of scale in corn production. Given that ethanol plants are more likely to locate in regions with higher corn yields and with more areas of corn production [8], results seem to indicate that these regions are the ones attracting ethanol plants.

Table 3. Non-spatial and spatial difference-in-differences (DID) estimation results with treatment being counties with an ethanol plant from 2015 to 2016.

\begin{tabular}{|c|c|c|c|c|c|c|}
\hline & \multicolumn{6}{|c|}{ Log Corn Contract Revenue } \\
\hline & \multicolumn{3}{|c|}{ DID OLS } & \multicolumn{3}{|c|}{ DID Spatial } \\
\hline & \multicolumn{2}{|c|}{ Coefficient } & Standard Error & \multicolumn{2}{|c|}{ Coefficient } & Standard Error \\
\hline Time dummy & -0.019 & & 0.110 & -0.071 & & 0.117 \\
\hline Ethanol plant dummy & -0.032 & & 0.127 & -0.034 & & 0.127 \\
\hline $\begin{array}{c}\text { Interaction of weight matrix } \\
\text { with treatment and time } \\
\text { dummy (Wdt) }\end{array}$ & & & & 0.010 & $* *$ & 0.004 \\
\hline $\begin{array}{l}\text { Ethanol plant dummy * time } \\
\text { dummy }\end{array}$ & 0.162 & & 0.185 & 0.155 & & 0.183 \\
\hline Entropy & -0.585 & & 0.536 & -0.605 & & 0.528 \\
\hline Tenure dummy & -0.455 & $* * *$ & 0.111 & -0.460 & $* * *$ & 0.111 \\
\hline Farm size dummy & 0.652 & $* * *$ & 0.086 & 0.650 & $* * *$ & 0.086 \\
\hline Intermediate farm & 0.334 & $* *$ & 0.157 & 0.332 & $* *$ & 0.155 \\
\hline Commercial farm & 1.226 & $* * *$ & 0.147 & 1.228 & $* * *$ & 0.147 \\
\hline Operator Age & 0.002 & & 0.005 & 0.002 & & 0.005 \\
\hline Operator education & -0.048 & & 0.054 & -0.050 & & 0.053 \\
\hline Farming dependent & 0.060 & & 0.127 & 0.056 & & 0.127 \\
\hline Urban-rural county index & 0.045 & * & 0.023 & 0.044 & * & 0.024 \\
\hline Low employment county & 1.100 & $* * *$ & 0.155 & 1.096 & $* * *$ & 0.153 \\
\hline Constant & 9.408 & $* * *$ & 0.456 & 9.444 & $* * *$ & 0.450 \\
\hline \multicolumn{3}{|c|}{ Average direct treatment effect (ADTE) } & & & & 0.155 \\
\hline \multicolumn{3}{|c|}{ Average treatment effect (ATE) } & & & & 0.187 \\
\hline \multicolumn{3}{|c|}{ Average indirect treatment effect (AITE) } & & & & $0.032^{* *}$ \\
\hline Number of observations & & & 3003 & & & 3003 \\
\hline $\mathrm{R}^{2}$ & & & 0.35 & & & 0.35 \\
\hline Counties & & & 629 & & & 629 \\
\hline
\end{tabular}

Notes: ${ }^{*} 10 \%, * * 5 \%$, and ${ }^{* * *} 1 \%$ levels of statistical significance. Standard errors are clustered at the county level. DID effect is equivalent to the average direct treatment effect (ADTE) in the spatial model. Wdt is the coefficient associated with the interaction of the weight matrix with the treatment and time dummy.

Farmers that owned over $50 \%$ of the land they operated received $46 \%$ less in corn revenues than those that operated mostly on rented land. This difference may be due to rental rates pressuring farmers that lease farmland to be more profitable [38]. Entropy, operator's age, and education did not have a statistically significant effect on local corn contract revenues. County characteristics also help explain the difference in revenues received by farmers. Corn revenues were higher in more rural locations. For instance, a change in the urban-rural index from 5 to 6 was associated with a $5 \%$ increase in corn revenues. This is likely a result of lower rental rates in less urban areas [39] and less off-farm jobs opportunities [40]. Lower rental rates may allow farmers to operate at a larger scale, and the lack of off-farm job opportunities may offer farmers more time to dedicate to farming. The positive effects from county characteristics (e.g., low employment county and urban-rural county index) aligned with farmers and farm characteristics may point to these counties with ethanol plants having a competitive advantage on corn production with respect to other counties. 
The AITE shows that farmers in counties adjacent to counties with ethanol plants experienced an increase of 3\% in their corn contract revenues (Table 3). A possible explanation for the positive effect on neighboring counties could be the expansion of corn production into these counties. This situation was, in fact, experienced in Brazil. During the 21st century sugarcane production expanded from the state of Sao Paulo, the leading state in ethanol and sugar production, to counties that bordered the state [41,42]. Farmers switched from grain and livestock production to sugarcane expanding sugarcane production to adjacent counties [41,42]. The size of the effect on corn contract revenues in adjacent counties resembles the changes in corn acreage found by Li et al. [43] due to increases in ethanol production capacity. The authors find that an increase in ethanol capacity can lead to a $3 \%$ increase in corn acreage. They also argue that corn price changes have little effect on corn acreage. As such, the benefits from being adjacent to counties with ethanol plants come from increases in the quantity of inputs sold and not from changes in prices, as Figure 2a,b indicate.

Costs associated with feedstock supply may influence the location of an ethanol plant, as such, observed ethanol plants may not be randomly assigned [24]. We repeated the analysis using instrumental variables for the endogenous variables: Ethanol plant dummy and ethanol plant dummy * time dummy. Similar to Miao [13] we use the ethanol production capacity aggregated at the state level. Although the state ethanol production capacity is correlated with the county-level ethanol production capacity, the state level is not dependent on the capacity of a single county [13]. We also use as instruments the interaction between the time dummy and the state ethanol production capacity and the U.S. Census index for low employment county in 2000. Information on the state ethanol production capacity comes from the Energy Information Administration [44]. Given the increase in the number of biofuel refineries since 2000 and the time it takes for a plant to be built and put into service, the general economy of the county in 2000 would influence an ethanol plant siting. Lower employment opportunities could mean lower labor costs for the ethanol plant. The index is not, however, expected to influence farmers' revenues in the years of 2015 and 2016 for the decision to grow corn can be made in a shorter time period (i.e., an annual decision). The results using the instrumental variables are similar to those in Table 3. The DID effect continues to be statistically insignificant and the statistically significant coefficients have the same signs and are similar in magnitude (Tables 3 and 4).

Table 4. Results from the two stage least square estimation for the years 2015 to 2016.

\begin{tabular}{|c|c|c|c|}
\hline & \multicolumn{3}{|c|}{ Log Corn Contract Revenue } \\
\hline & \multicolumn{2}{|c|}{ Coefficient } & \multirow{2}{*}{$\begin{array}{c}\text { Standard Error } \\
0.504\end{array}$} \\
\hline Time dummy & -0.204 & & \\
\hline Ethanol plant dummy & 1.248 & & 1.465 \\
\hline Ethanol plant dummy ${ }^{*}$ time dummy & 1.030 & & 1.606 \\
\hline Entropy & -0.579 & & 0.597 \\
\hline Tenure dummy & -0.393 & $* * *$ & 0.134 \\
\hline Farm size dummy & 0.488 & $* * *$ & 0.150 \\
\hline Intermediate farm & 0.349 & * & 0.201 \\
\hline Commercial farm & 1.279 & $* * *$ & 0.184 \\
\hline Operator age & -0.001 & & 0.005 \\
\hline Operator education & -0.038 & & 0.067 \\
\hline Farming dependent & 0.102 & & 0.226 \\
\hline Urban-rural county index & 0.029 & & 0.036 \\
\hline Constant & 9.235 & $* * *$ & 0.611 \\
\hline Kleibergen-Paap rk Wald F statistic & & & 9.127 \\
\hline \multirow[t]{2}{*}{ Hansen J statistic } & & & 1.966 \\
\hline & & & 0.161 \\
\hline RMSE & & & 1.36 \\
\hline Number of observations & & & 3003 \\
\hline Counties & & & 629 \\
\hline
\end{tabular}

RMSE are the root mean squared errors. P-values are in the brackets. Standard errors are clustered at the county level. Instrumental variables are ethanol production capacity at the state level, the interaction between the time dummy and the state level ethanol production capacity, and the index for low employment county from the 2000 U.S. Census. Hansen J statistic test of the validity of over-identifying restrictions does not reject the null hypothesis that instruments are exogenous. The Kleibergen-Paap test is close to 10 and may indicate a good instrument [45]. 
The lack of an effect of ethanol plant location on local corn contract revenues supports ideas presented in other studies as to: (1) Other drivers rather than ethanol plant location affect changes in planted corn acreage [10]; (2) effects of the ethanol plant location may be temporary, dissipating in months [4] and as such would not be captured in this model; (3) counties with higher specialization in corn production attract a new ethanol plant [8]; or (4) there are no corn price premiums in counties with an ethanol plant [2]. It is important to highlight that our results are limited to revenues from corn contracts. We focused on this form of procurement since it has been shown to be an advantageous and main form of procurement of feedstock used by ethanol plants [46]. As such, our results may not be expanded to interpret the effects on other corn markets (i.e., spot markets). We leave this analysis to future studies.

\section{Conclusions}

The impact of ethanol plants on corn prices and corn acreage has been the topic of various studies. This study investigates a phenomenon observed between counties with ethanol plants and those without ethanol plants. That is, the average corn revenues in counties with an ethanol plant are higher than in counties without, at similar corn prices. Non-spatial and spatial difference-in-differences models are estimated using ARMS data. The models account for changes over two-years in corn contract revenues and estimate the impact of ethanol plants on local corn contract revenues. The effect from the presence of ethanol plants on the corn contract revenues in their counties was inconclusive. The higher revenues observed are probably due to factors related to the operator (i.e., capital and tenure), size of the operation, and characteristics of the county. Results suggest that ethanol plants may be located in areas with competitive advantage in corn production (i.e., areas specialized in corn production and with higher corn yields). While we do not see a statistically significant impact from ethanol plants on corn revenue in the county where the ethanol plant is located, we do see a positive impact in adjacent counties. It is likely that although the county where the ethanol plant is located may have a competitive advantage in corn production, its neighbors may not. As such, neighboring counties face gains in revenues with the location of the ethanol plant.

Author Contributions: Conceptualization, A.L.K. and A.C.S.A; methodology, A.L.K and A.C.S.A; data curation, A.L.K and A.C.S.A; formal analysis, A.L.K and A.C.S.A; writing-original draft preparation, A.L.K and A.C.S.A; writing-review and editing, A.L.K and A.C.S.A; visualization, A.C.S.A; supervision, A.L.K.

Funding: This research received no external funding.

Acknowledgments: We thank the anonymous reviewers and the editor. We thank the comments given by those present at the 2019 Australian Agricultural and Resource Economics Society Meeting. We thank Assistant Professor of Geography Dr. Gabriel Granco for his suggestions for the spatial weight matrix.

Conflicts of Interest: No conflicts of interest to declare.

\section{References}

1. RFA. Annual Industry Outlook. Available online: http://www.ethanolrfa.org/resources/publications/outlook/ (accessed on 29 May 2017).

2. Katchova, A.L. The spatial effect of ethanol biorefinery locations on local corn prices. In Proceedings of the Agricultural and Applied Economics Association's 2009 Annual Meeting, Milwaukee, WI, USA, 26-28 July 2009.

3. Miller, E.; Mallory, M.L.; Baylis, K.R.; Hart, C.E. Basis effects of ethanol plants in the U.S. Corn Belt. In Proceedings of the Agricultural \& Applied Economics Association's 2012 AAEA Annual Meeting, Seattle, WA, USA, 12-14 August 2012; p. 23.

4. Lewis, K.E. The Impact of Ethanol on Corn Market Relationships and Corn Price Basis Levels; Michigan State University: East Lansing, MI, USA, 2010.

5. McNew, K.; Griffith, D. Measuring the Impact of Ethanol Plants on Local Grain Prices on JSTOR. Rev. Agric. Econ. 2005, 27, 164-180. [CrossRef] 
6. O'Brien, D.M. The Effects of the Micro-Market Structure for Kansas Grain Elevators on Spatial Grain Price Differentials. In Proceedings of the NCCC-134 Conference on Applied Commodity Price Analysis, Forecasting, and Market Risk Management, St. Louis, MO, USA, 20-21 April 2009.

7. Behnke, K.; Fortenbery, T.R. The Impact of Ethanol Production on Local Corn Basis. In Proceedings of the NCCC-134 Applied Commodity Price Analysis, Forecasting, and Market Risk Management, St. Louis, MO, USA, 18-19 April 2011.

8. Sarmiento, C.; Wilson, W.W.; Dahl, B. Spatial Competition and Ethanol Plant Location Decisions: Spatial Competition and Ethanol Plant Location. Agribusiness 2012, 28, 260-273. [CrossRef]

9. Lambert, D.M.; Wilcox, M.; English, A.; Stewart, L. Ethanol plant location determinants and county comparative advantage. J. Agric. Appl. Econ. 2008, 40, 117-135. [CrossRef]

10. Ifft, J.; Rajagopal, D.; Weldzuis, R. Ethanol Plant Location and Land Use: A Case Study of CRP and the Ethanol Mandate. Appl. Econ. Perspect. Policy 2019, 41, 37-55. [CrossRef]

11. Fatal, Y.S.; Thurman, W.N. The Response of Corn Acreage to Ethanol Plant Siting. J. Agric. Appl. Econ. 2014, 46, 157-171. [CrossRef]

12. Motamed, M.; McPhail, L.; Williams, R. Corn area response to local ethanol markets in the United States: A grid cell level analysis. Am. J. Agric. Econ. 2016, 98, 726-743. [CrossRef]

13. Miao, R. Impact of Ethanol Plants on Local Land Use Change. Agric. Resour. Econ. Rev. 2013, 42, $291-309$. [CrossRef]

14. Du, X.; Hennessy, D.; Edwards, W.A. Does a rising biofuels tide raise all boats? A study of cash rent determinants for Iowa farmland under hay and pasture. J. Agric. Food Ind. Organ. 2008, 6. [CrossRef]

15. Miller, E. How Does Changing Ethanol Capacity Affect Local Corn Basis? Available online: https:// policymatters.illinois.edu/how-does-changing-ethanol-capacity-affect-local-corn-basis/ (accessed on 17 December 2019).

16. Gallagher, P.; Wisner, R.; Brubacker, H. Price relationships in processors' input market areas: Testing theories for corn prices near ethanol plants. Can. J. Agric. Econ. 2005, 53, 117-139. [CrossRef]

17. Fatal, Y.S. Ethanol Plant Siting and the Corn Market; North Carolina State University: Raleigh, NC, USA, 2011.

18. Haddad, M.A.; Taylor, G.; Owusu, F. Locational Choices of the Ethanol Industry in the Midwest Corn Belt. Econ. Dev. Q. 2010, 24, 74-86. [CrossRef]

19. Rask, K.N. Clean air and renewable fuels: The market for fuel ethanol in the US from 1984 to 1993. Energy Econ. 1998, 20, 325-345. [CrossRef]

20. Blank, D. Will Farmers Benefit from Shelbyville's Ethanol Plant? Maybe. Available online: https://www.batesvilleheraldtribune.com/news/local_news/will-farmers-benefit-from-shelbyvilles-ethanol-plant-maybe/article_2d814894-e148-5304-9480-52150fe49d1f.html (accessed on 17 December 2019).

21. Hargreaves, S. Calming ethanol-crazed corn prices. CNNMoney, 30 January 2007.

22. Katchova, A.L. Agricultural Contracts and Alternative Marketing Options: A Matching Analysis. J. Agric. Appl. Econ. 2010, 42, 261-276. [CrossRef]

23. Porter, M.E. The Competitive Advantage: Creating and Sustaining Superior Performance; Free Press: New York, NY, USA, 1985.

24. Granco, G.; Sant'Anna, A.C.; Bergtold, J.S.; Caldas, M.M. Factors influencing ethanol mill location in a new sugarcane producing region in Brazil. Biomass Bioenergy 2018, 111, 125-133. [CrossRef]

25. Delgado, M.S.; Florax, R.J.G.M. Difference-in-differences techniques for spatial data: Local autocorrelation and spatial interaction. Econ. Lett. 2015, 137, 123-126. [CrossRef]

26. Ramsey, J.B. Tests for Specification Errors in Classical Linear Least-Squares Regression Analysis. J. R. Stat. Soc. 1969, 31, 350-371. [CrossRef]

27. Pregibon, D. Data Analytic Methods for Generalized Linear Models; University of Toronto: Toronto, ON, Canada, 1979.

28. StataCorp. Stata 14 Base Reference Manual; Stata Press: College Station, TX, USA, 2015.

29. Merryman, S. USSWM: Stata Module to Provide US State and County Spatial Weight (Contiguity) Matrices; Statistical Software Components S448405; Boston College Department of Economics: Boston, MA, USA, 2008.

30. ARMS Team. ARMS Farm Financial and Crop Production Practices-Documentation. Available online: https://www.ers.usda.gov/data-products/arms-farm-financial-and-crop-production-practices/ documentation/\#about (accessed on 8 November 2019). 
31. Nebraska Energy Office Energy Statistics. Available online: http://www.neo.ne.gov/ (accessed on 1 October 2017).

32. MacDonald, J.M.; Perry, J.; Ahearn, M.C.; Banker, D.; Chambers, W.; Dimitri, C.; Key, N.; Nelson, K.E.; Southard, L.W. Contracts, Markets, and Prices: Organizing the Production and Use of Agricultural Commodities; United States Department of Agriculture: Washington, DC, USA, 2004.

33. Sesmero, J.P.; Perrin, R.K.; Fulginiti, L.E. A Variable Cost Function for Corn Ethanol Plants in the Midwest: A Variable Cost Function for Corn Ethanol. Can. J. Agric. Econ. 2016, 64, 565-587. [CrossRef]

34. MacDonald, J.M.; Korb, P. Agricultural Contracting Update: Contracts in 2008; Economic Information Bulletin; DIANE Publishing: Collingdale, PA, USA, 2011; p. 43.

35. Katchova, A.L.; Miranda, M.J. Two-Step Econometric Estimation of Farm Characteristics Affecting Marketing Contract Decisions. Am. J. Agric. Econ. 2004, 86, 88-102. [CrossRef]

36. Mishra, A.; Tegegne, F.; Sandretto, C.L. The Impact of Participation in Cooperatives on the Success of Small Farms. J. Agribus. 2004, 22, 59604.

37. Hoppe, R.A.; MacDonald, J.M. Updating the ERS farm typology. USDA-ERS Econ. Inf. Bull. 2013. [CrossRef]

38. Garcia, P.; Sonka, S.T.; Yoo, M.S. Farm Size, Tenure, and Economic Efficiency in a Sample of Illinois Grain Farms. Am. J. Agric. Econ. 1982, 64, 119-123. [CrossRef]

39. Kuethe, T.; Ifft, J.; Morehart, M.J. The Influence of Urban Areas on Farmland Values. Choices 2011, 26, 1-7.

40. Mishra, A.K.; El-Osta, H.S.; Morehart, M.; Johnson, J.; Hopkins, J. Income, Wealth, and the Economic Well-Being of Farm Households; Resource Economics Division, Economic Research Service, U.S. Department of Agriculture: Washington, DC, USA, 2002; p. 77.

41. Granco, G.; Caldas, M.M.; Bergtold, J.S.; Sant'Anna, A.C. Exploring the policy and social factors fueling the expansion and shift of sugarcane production in the Brazilian Cerrado. GeoJournal 2017, 82, 63-80. [CrossRef]

42. Sant'Anna, A.C.; Shanoyan, A.; Bergtold, J.S.; Caldas, M.M.; Granco, G. Ethanol and sugarcane expansion in Brazil: What is fueling the ethanol industry? Int. Food Agribus. Manag. Rev. 2016, 19, 163-182. [CrossRef]

43. Li, Y.; Miao, R.; Khanna, M. Effects of Ethanol Plant Proximity and Crop Prices on Land-Use Change in the United States. Am. J. Agric. Econ. 2019, 101, 467-491. [CrossRef]

44. USEIA. U.S. Fuel Ethanol Plant Production Capacity. Available online: https://www.eia.gov/petroleum/ ethanolcapacity/ (accessed on 26 July 2018).

45. Boberg-Fazlić, N.; Sharp, P. Does Welfare Spending Crowd Out Charitable Activity? Evidence from Historical England Under the Poor Laws. Econ. J. 2015, 127, 50-83. [CrossRef]

46. Schmidgall, T.J.; Tudor, K.W.; Spaulding, A.D.; Winter, J.R. Ethanol marketing and input procurement practices of US ethanol producers: 2008 survey results. Int. Food Agribus. Manag. Rev. 2010, 13, 137-156. 